\title{
Integrating Study Skills in First Year Politics Modules: A Case Study
}

Dr Judith Murray

Lecturer

Department of Politics

Newcastle University

Newcastle upon Tyne, United Kingdom

NE1 7RU

\begin{abstract}
This paper will present an approach to redesigning a first year Politics module at a Russell Group university in the United Kingdom with a focus on integrating study skills, employability skills and research skills. The prior content of the module will be presented along with the rationale for the module redesign. Key skill and learning outcomes will be discussed, with an emphasis on realignment of the assessment regime to a mixed approach of both formative and summative assessment designed to improve the transition to university teaching. Active learning pedagogy (Bonwell, 1991) incorporated into the redesigned module will be presented, including the use of interactive personal response systems in lectures as well as student generated research topics. Seminar structure will be discussed, noting the linking of seminar tasks to lectures and the use of student portfolios to master key study skills. Finally, student feedback regarding their first experience of the module redesign will be presented, as well as the feedback of the assessment results, to gain insight into the implications of the module redesign.
\end{abstract}

Keywords: Study skills; transition to university; module design; active learning; first year students 


\section{Introduction}

Tinto (1987) outlines several areas where educators can improve the first year student transition experience and ultimately bolster academic achievement. Of primary importance is acquiring the study skills needed for academic success. However, more is expected of universities in order to equip students with a wider set of skills that are transferable to contexts outside of their disciplines (Drummond et al., 1998). As a result, the task of educators to ensure students are equipped with the desired skill set, not only for the university environment but for future employability, has become more challenging. There are several approaches to integrating these skills into curriculum, but as Wingate (2006) notes, the most effective strategy for longterm student development both during and after university is to present and teach the required skills from the inception of a student's university experience. This approach suggests the first year of university is exceedingly important in a variety of ways. Indeed, Barr and Jackson (2018) emphasise the importance of the first year experience, noting it to be the primary factor influencing a student's subsequent success. With so much at stake, the design and delivery of first year modules has become increasingly relevant and important in the higher education environment.

\section{The importance of study skills in first year delivery}

The transition to university study can be very difficult on a number of levels. Students must become familiar with their discipline, but also must navigate the 'informal and implicit' demands at university (Gibney et al., 2011). Many universities have recognised that students entering a degree course do not have the necessary study skills to be successful, thereby making that transition more difficult (Durkin et al., 2002). If a student enters university without a core set of study skills in place, their likelihood of success diminishes. A lack of attention to addressing this essential aspect of university life frequently leads to low retention rates and under achievement (Lowe et al., 2003). Recent efforts to address the study skills deficit have focused on students identified as 'at risk', directing them to 'bolt-on' study skills courses offered in dedicated learning support centres (Groves et al., 2010). However, confining support strategies to a narrow subset of students likely makes assumptions concerning the skill set of the full cohort of students, and fails to recognise the necessity of adequately preparing all students for the independent learning required in higher education and beyond in the workplace.

Villarreal and Martinez (2018) note that courses that include study skills components yield multiple benefits, including improved academic success, retention and self-efficacy. To maximise these benefits, inclusive approaches that teach students how to study within their 
own subject discipline are likely to be more successful (Durkin et al., 2002). Indeed, Wingate (2006) notes the importance of learning how to study effectively at university can not be separated from subject content and the process of learning. Furthermore, integrating study skills into first year delivery initiates students to the standards expected in their specific academic discipline. As a result, a study skills programme can be tailored to the specific requirements of the degree programme. Research to understand the benefits of study skills courses at subject level can be found primarily in design and engineering as well as computer science and psychology (Coughlan et al., 2011). Research concerning the impact of module redesigns and study skills programmes in politics are not common, Barr and Jackson (2018) being a very recent exception.

\section{Overview of prior iteration of module}

The module that is the focus of this examination is a compulsory first year, first semester module within a Single Honours Politics programme. The module is also compulsory for Politics and Sociology programmes, and Government and European Union Studies (GEUS), and can be taken as an elective by students on other programmes. The cohort size has been increasing steadily and now is around 160. It is not a prerequisite to have studied Politics before to be accepted into this particular module, or indeed the degree programme. Consequently, there is a diverse range of academic backgrounds in the cohort in terms of previous study of the subject. The prior iteration of the module was delivered using a combination of lectures ( $12 \times 1$ hour), seminars (10 x 1 hour) and workshops ( $7 \times 1$ hour), with a particular emphasis on surgeries and feedback sessions ( $18 \times 1$ hour) focusing on the specific assessment regime. The original mode of assessment contained 2 elements: a 1500 word essay representing $50 \%$ of the total module mark and a team debate constituting the remaining $50 \%$ of the total module mark. The unique feature of the essay element of the module was not the assessment itself but rather the process of student feedback. Students submitted their essay very early in the semester (week four) and received a 15 minute one-to one feedback session the week after submission. This one-off process accounts for the large number of hours devoted to feedback in the overall module construction. Concerning the student debate, debate teams were comprised of 5-8 students and the debate topic was standardised across all groups. Feedback and marks were given to students immediately after the debate.

\section{Method/rationale for module redesign}

There were several areas in this module that were seen as benefitting from redesign: (1) perceived shortcomings in student attainment in subsequent stages related to the execution of particular skills related to university study and (2) an emerging focus and intent on integration 
of research methods teaching through all stages of study in the degree programme. The lecture series in the prior iteration of the module focused only on the topics related to the two assessments and assumed a high level of prior political knowledge concerning concepts and research techniques. This approach lacked broader context related to transitioning to higher education and acquiring the necessary skills to successfully study at university level. These skills include knowledge of relevant political theories and research methods (Dickovick, 2009), and practical skills related to writing effectively (Wingate et al., 2011), referencing (Hendricks et al., 2000) and importantly, effectively engaging with feedback (Blair, 2017). Further, soft transferable skills (Briggs et al., 2012) such as communication, engaging with academic staff, problem solving and intra-personal skills including self-reflection were also not addressed in the prior module iteration. The importance of acquiring this full range of both hard and soft skills is particularly salient considering the emphasis on universities to prepare students for the workplace (Harvey 2005). Further, the diversity of the cohort and their varying experience of study broadly, and studying politics specifically, necessitated an inclusive approach to facilitate successful transition to university life that extends beyond induction programmes that are usually restricted to the first few weeks of the academic year (Blair, 2017).

The politics department at this university has recognised that integrating research methods teaching early in a degree programme lends itself to higher attainment at all subsequent levels. For undergraduate politics students however, the value of research methods is not always understood (Bergbower, 2017). There also exists an expectation that introductory courses emphasise content knowledge as opposed to methods or analysis (Dickovick, 2009). However, engaging with politics without any knowledge of research methods presents a steep learning curve for those students who had not previously studied politics, but also likely the full student cohort. Indeed, one of the benefits of engaging in methods teaching early is to begin to develop key research fundamentals, foster critical reading of research, and the familiarisation and confidence to engage with data (Bergbower, 2017). Further, developing pedagogy that provides opportunities for applied research methods skills enhances student engagement (Barr et al., 2018). In many instances of undergraduate teaching, a research methods module may be offered in only one semester and addresses the full range of research design: conceptualising and defining a research problem, conducting literature reviews, collecting and analysing data (quantitative and qualitative) as well as writing and interpreting results. The volume of material is often overwhelming for students, creating what Papanastasiou and Zembylas (2008) call 'research methods anxiety'. An incremental and integrated approach to presenting research methods over the duration of a degree programme is an appropriate pedagogical method to 
reducing student anxiety as well as fostering the skills necessary to be successful through the entire degree programme.

\section{New iteration of module}

The new iteration of the module is comprised of lectures ( $20 \times 1$ hour) and seminars $(9 \times 1$ hour) and focuses on embedding study skills and research methods into the subject content using active learning techniques. Active learning requires students to do meaningful learning activities and think about what they are doing (Prince 2013). Bonwell et al. (1991) extend this definition by noting that active learning is 'a method of learning in which students are actively or experientially involved in the learning process'. One powerful way of promoting active learning is to include formative classroom assessment (Bonwell 1997). This was one of the primary revisions in this module; a realignment of the assessment regime to reflect mixed assessments including a sequential formative assessment strategy and supporting summative work. The new assessment regime includes four elements: a 500 word writing assignment worth $20 \%$ of the total mark of the module, an annotated bibliography reflecting 10 sources worth $20 \%$ of the final mark, an 1800 word essay worth $50 \%$ of the total mark, and a seminar portfolio of formative work supporting embedded study skills worth $10 \%$ of the total mark. All of the assessed work in the module is designed to be sequential in nature, reflecting an individual research project from inception to completion, and supporting the key learning outcomes of the module: how politics researchers develop strategies to analyse relevant and contemporary questions, an awareness of the use of data in political debate, and the ability to identify and draw information from a wide range of credible and relevant source material.

The first assessment of a 500 word writing assignment underpins all the subsequent work in the module. Students are asked to write a short piece on what they perceive to be the most important political problem in the world today. The piece is to contain no referencing but only be a personal expression of their views, written clearly and succinctly using correct grammar and punctuation. This exercise is used to reflect the first stages in the research process, that being conceptualisation and definition of a research problem. The student self-generates a problem or issue that is of interest or importance to them, thereby providing a higher level of learner autonomy. Further, this very early task is used to identify any students who have particularly concerning issues with writing. If a student is identified as having these difficulties, we are able to provide the additional support needed and proactively refer them to additional services offered in the department and at the university. 
From this exercise, the module proceeds to introduce the second stages of the research process: conducting literature reviews and collecting and finding both qualitative and quantitative data. Using the self-generated 'most important problem', student's begin to conduct a literature review ultimately presenting an annotated bibliography of 10 sources related to their 'most important problem'. The benefit of this exercise is twofold: firstly, the propensity to actively research and engage with relevant literature is likely to be greater as the topic is self-generated and based on the students individual interest, and secondly, students will likely inadvertently challenge their own points of view related to their self-generated topic using the existing literature and current research. In other words, it is expected that students may find evidence that challenges their presuppositions about their self-generated topic, thereby creating opportunities for critical thinking and self-reflection. This exercise also engages with core skills such as the referencing archetype described by Angelil-Carter (1995, p. 1):

'We have understood referencing as the superficial manifestation of a much deeper, elemental feature of academic writing, which is the selection from sources, and subsequent integration and synthesis of knowledge and ideas into a coherent whole'.

In the annotated bibliography, students are asked to identify the research methods used in their source, and to address why and how any particular source will be useful in their research. Identifying these components requires students to engage more fully with relevant literature and actively engage in several critical thinking skills including analysis, determining relevancy, and evaluating credibility.

The final sequence in the assessment regime reflects the final stages of the research process, that being writing and interpreting results. Students prepare an 1800 word essay concerning their 'most important problem'. The essay is intended to address the broader themes around their self -generated topic and demonstrate how arguments are supported in an academic setting. By producing an extended piece of writing, students are able to explore their 'most important problem' more fully, thereby replicating (on a much smaller scale) the full research process. This sequential approach to assessment, building on the prior exercises, facilitates the students ability to both think and learn and to grasp the fundamental study skills necessary to succeed in higher education (Oehlers 2006). Sequential assessment methods have been used frequently in engineering disciplines that are project based. Applying a similar pedagogy in the humanities is less well known but could have significant benefits to students, not least making it clear to the students how knowledge is generated at university level, but also how assessment is 
related to practice. To demonstrate the sequential relationship between the three pieces of work, a student example is provided in Appendix A.

The lecture programme supports the assessment regime and provides the necessary context for students who have never studied politics while simultaneously offering those with prior experience studying politics an in-depth introduction to higher order research skill attainment. A critical aspect of the lecture programme is the use of a student response system. A student response system (SRS) is a combination of hardware and software that enables the instructor to pose real-time questions to students (Collins 2007). Instructors present problems, questions or quizzes to students to confirm understanding, or promote discussion and debate. The students usually register their responses using handheld clickers, although in this case personal digital equipment that is Wi-Fi enabled is used. After students transmit their responses, the software compiles and displays the results. Trends or changes in student thinking are easily charted using histograms or percentages. Student response systems have been adopted in large enrolment modules that rely on traditional lecture delivery to foster deeper learning and engagement (Trees et al., 2007). In this case, SRS is used most frequently to ensure understanding of basic concepts, particularly related to research methods and theory. When there is clear evidence that students are not clear on any concepts, the topics can be revisited immediately to ensure student understanding. This has been a particularly novel approach in this module as the adoption of SRS is very limited in the department.

The seminar programme runs in parallel to the lecture programme and assessed tasks and focuses exclusively on study and employability skills acquisition including:

- $\quad$ Professional conduct including email etiquette, office hours, student learning responsibilities, staff responsibilities, intra and inter-personal communication, engaging with academic staff, and giving and using feedback effectively.

- Writing techniques including brainstorming, planning, structuring, time management and departmental essay structure requirements.

- $\quad$ Referencing and bibliographies including both the Harvard and Chicago systems.

- Critical thinking including evaluating sources, evaluating statistics, facts and opinions, and finding and identifying theory and method.

- Transferable skills including identifying transferable skills and communicating transferable skills to a potential employer 
Students are required to complete weekly tasks relating to the skills detailed above. An overview of each task is presented in the seminar with supporting activities to ensure clarity regarding each skill. Many of the tasks are directly related to the assessed work, for example all writing technique tasks involve the student's self generated 'most important problem', and referencing and critical thinking tasks relate to the student's annotated bibliography. Student portfolio's are then submitted at the end of the module. Each portfolio also includes several selfreflective exercises detailing the student's perceptions of their learning throughout the module. Table 1 details the interrelationship between the lecture, seminar and assessment programme structure.

[insert Table 1 about here]

\section{Measurements of module redesign/implications}

There are several measurements that can be used to assess the success of the redesigned module. Firstly, the module mark distribution was wider than in previous years, particularly utilising the 'first' $(70+)$ level marking distribution. This suggests greater use of the full range of marks available for assessment. The importance of this practice rests in issues of quality assurance for external moderators and recognition of higher student performers. Interestingly, as seen in Table 2, there were also more 'fails' in the new iteration of the module than in prior years as well.

\section{[Insert Table 2 about here]}

Overall, attendance at lectures and seminars was greater than the prior year. Concerning attendance, there is no overarching compulsory attendance policy at this university. Despite this, lecture attendance rose by $12.2 \%$ overall and the mean seminar attendance was $80.2 \%$ over 9 seminar groups which reflects one of the highest averages in the Department.

Students are able to provide module feedback via EvaSys online student surveys that are posted on their virtual learning environment (VLE) account. Feedback is requested as the end of the semester approaches. While the student feedback was mixed concerning the module, it is important to note the student feedback response rate for this module was only $35.6 \%$. This low response rate is not uncommon, but highly problematic as in order for student feedback surveys to provide meaningful and actionable data, they must be representative of the population of any given module (Nulty 2008). Despite the response rate problem, positive feedback included 
being able to pick a research topic that the student found personally interesting and following the research process from beginning to end:

'Giving the students the ability to choose the topic of the essay/module was the best part was able to enjoy the research element much more.'

'The ability to self-generate a topic of interest rather than having questions prescribed. I highly enjoyed the research and freedom of the module, it fit my personal learning style.'

Additionally, several students noted how the module was useful in facilitating the transition from secondary school to post-secondary school.

'Learning about academic skills was definitely useful and will help me throughout my degree so learning about it so early will save a lot of time later on.'

'I liked the simplicity of this module and the way it eased us into the university.'

Negative feedback primarily related to the content being perceived as too rudimentary:

'Some of the lecture material was a low level of education and seemed basic at best.'

'Often many students felt that the module would get boring, with many lectures teaching basic essay rules that many students knew already.'

Others commented on module structure and assessment deadlines:

'The lectures on the assignments and annotated bibliography were too near the due dates of the assignments themselves.'

Of the total student response, $54.5 \%$ rated the module as satisfactory, very satisfactory or highly satisfactory.

\section{Discussion and Future Revisions}

There often seems to be a disconnect between what instructors believe students require to be successful at university and what students perceive as necessary for them to succeed. What is clear however is instructors at UK universities see and experience that students from all 
backgrounds are not prepared for the independent learning required in higher education (Wingate, 2006). The typical way to address these deficiencies has been to provide 'bolt-on' support for at students perceived to be 'at risk'. However, as Blythman and Orr (2002) have pointed out, students from all backgrounds need study skill instruction to successfully achieve and progress within the higher education system, and ultimately into the workplace. As active learning methods are incorporated into large course pedagogy to facilitate skill attainment, instructors frequently experience student resistance (Cooper et al., 2000). For example, in a classroom using a student response system, students' expectations for their role in the classroom must shift to accommodate new teaching and learning activities that encourage students to actively engage with the material. Students may find that these activities violate expectations that, in a large course, the instructor will simply provide information that they then memorise for tests. This situation appeared to occurred in this module as student feedback suggested there was a lack of subject specific 'information' to use in assessments or other modules:

'The module has been about teaching us skills rather than expanding our political knowledge to use in other modules.'

There was some suggestion by students that the name of the module did not clearly represent the content of the module. We often seek to attract students to our modules by offering novel and exciting module names. However, managing student expectations through accurate module naming is an important aspect of effective practice. This is sometimes problematic when teaching loads are shifted within a department and staff are moved to teach on different modules outside of student module selection deadlines.

As a follow up, the module name has been changed to better reflect the content of the module for the next academic year. As per student feedback, the structure of the assessment regime is being revised in terms of hand-in dates, and the lecture schedule is being realigned to support student assessment in other modules. For example, lectures and activities relating to referencing and writing techniques will be introduced in relation to other written assessment hand-in dates for other modules to better optimise student skill attainment. Obtaining fuller data concerning student views will be necessary to assess where the module positions itself in the future. Further, assessing whether this new approach has had any impact on subsequent student success in years 2 and 3 at university will be a necessary task to ensure the module is effectively meeting objectives. The success of embedding study skills into discipline specific modules from the beginning of a student's university experience is a long term strategy to 
ensure the learning of all students throughout the entire degree programme. This conception supports students in gradually building the skills necessary to be successful in higher education and ultimately in the workplace. Academic staff should be open to incorporating active learning strategies within their regular teaching to support this holistic approach to learning. 


\section{References}

Angelil-Carter, S. (2000) Stolen Language?: Plagiarism in Writing. London: Routledge.

Barr, M. and Jackson, L.H. (2018) Enhancing Delivery and Assessment: A Case Study in Module Redesign for Improved Transition Into Higher Education. Journal of Political Science Education, 14(3), pp. 390-399.

Bergbower, Matthew L. (2017) When are Students Ready for Research Methods? A Curriculum Mapping Argument for the Political Science Major. Journal of Political Science Education, 13(2), pp. 200-210.

Blair, A, (2017) Understanding first year students' transition to university: A pilot study with implications for student engagement, assessment and feedback. Politics, 37(2), pp. 215228.

Blythmann, M. and Orr, S. (2002) 'A joined-up approach to student support', in Peelo, M. and Wareham, T. (eds), Failing Students in Higher Education, Buckingham: The Society for Research into Higher Education.

Bonwell, C. (1997) Using Active Learning as Assessment in the Postsecondary Classroom. The Clearing House, 71(2), pp. 73-76.

Bonwell, C and Eison, J. (1991). Active Learning: Creating Excitement in the Classroom. AEHEERIC Higher Education Report No. 1. Washington, D.C.: Jossey-Bass.

Briggs, A.R.J., Clark, J. and Hall, I. (2012) Building bridges: understanding student transition to university. Quality in Higher Education, 18(1), pp. 3-21.

Cooper, James L. and Robinson, P., (2000) The Argument for Making Large Classes Seem Small. New Directions for Teaching and Learning. 2000(81), pp.5-16.

Coughlan, J and Swift, S. (2011) Student and Tutor Perceptions of Learning and Teaching on a First Year Study Skills Module in a University Computing Department. Educational Studies, 37(5), pp. 529-539.

Dickovick, J. Tyler. (2009) Methods in the Madness: Integrative Approaches to Methodology in Introductory Comparative Politics. Journal of Political Science Education, 5(2), pp. 138153.

Drummond, I., Nixon, I. and Wiltshire, J. (1998) Personal transferable skills in higher education: the problems of implementing good practice. Quality Assurance in Education, 6(1), pp. 19-27.

Durkin, K. and Main, A. (2002) Discipline-based Study Skill Support for First Year Undergraduate Students. Active Learning in Higher Education, 3(1), pp. 24-39.

Gibney, A., Moore, N., Murphy, F. and O’Sullivan, S. (2011)The First Semester of University Life: 'Will I be Able to Manage it all?' Higher Education, 62(3), pp. 351-366. 
Groves, M., Bowd, B., and Smith, J. (2010) Facilitating experiential learning of study skills in sport students. Journal of Further and Higher Education, 34(1), pp. 11-22.

Harvey, L., (2005) Embedding and Integrating Employability. New Directions for Institutional Research, 2005(128), pp. 13-28.

Hendricks, M and Quinn, L. (2000) Teaching Referencing as an Introduction to Epistemological Empowerment. Teaching in Higher Education, 5(4), pp. 447-457.

Kolb, D. (1984) Experiential Learning: Experience as the Source of Learning and Development. New Jersey, Prentice Hall.

Lowe, H. and Cook, A. (2003) Mind the Gap: Are Students Prepared for Higher Education? Journal of Further and Higher Education, 27(1), pp. 53-76.

Nulty, D. (2008) The adequacy of response rates to online and paper surveys: what can be done? Assessment and Evaluation in Higher Education, 33(3), pp. 301-314.

Oehlers, D. J. (2006) Sequential Assessment of Engineering Design Projects at University Level. European Journal of Engineering Education, 31(4), pp. 487-495.

Papanastasiou, E.C. and Zembylas, M. (2008) Anxiety in Undergraduate Research Methods Courses: Its Nature and Implications. International Journal of Research and Method in Education, 31(2), pp. 155-167.

Prince, M., (2004) Does Active Learning Work? A Review of the Research. Journal of Engineering Education., 93(3), pp.223-231.

Tinto, V. (1987) Leaving College: Rethinking the Causes ad Cures of Student Attrition. Chicago: The University of Chicago Press.

Trees A. R. and Jackson, M. H. (2007) The Learning Environment in Clicker Classrooms: Student Processes of Learning and Involvement in Large University Devel Courses Using Student Response Systems. Learning, Media and Technology, 32(1), pp. 21-40.

Villarreal, V. and Martinez, A. (2018) Assessing Study Skills in College Students: A Review of Three Measures. Journal of College Student Development, 59(5), pp. 629-635.

Wingate, U. (2006) Doing away with study skills. Teaching in Higher Education, 11(4), pp. 457469.

Wingate, U. and Andon, N. (2011) Embedding academic writing instruction into subject teaching: A case study. Active Learning in Higher Education, 12(1), pp. 69-81. 


\section{APPENDIX A}

\section{What is the most important political problem today?}

Over the past few years, nationalism has been on the rise in the USA and it has become a hotly debated topic within the field of area studies surrounding the USA. This dangerous ideology has become more prominent since the presidential election of Donald Trump in 2016. Nationalism in the USA is the biggest political problem of today as the ideology promotes racism, Islamophobia and anti-Semitism, attitudes which should be unacceptable in the $21^{\text {st }}$ century, especially in a liberal country. Nationalism was the basis of Nazism in Germany throughout World War Two and this ended in the mass genocide of the Jewish. Surely this isn't an ideology we want to see return. The United States is currently the world's greatest superpower and it has a historical reputation of being the land of freedom, therefore it is becoming increasingly worrying to watch president Trump promote such ideals as this gives the message to other countries that this is an acceptable and justifiable political stance.

President Trump has shown his nationalistic tendencies since the beginning of his presidency, for example he issued an executive order to put in place a travel ban on the citizens of seven Muslim majority countries. This added to Trump's 'America first' narrative in which he pledged to put an end to mass immigration. One of the countries on the list was Syria, a country which is suffering great political turmoil which has resulted in many citizens fleeing as refugees. The nationalist demand for the USA to stop taking in refugees who have suffered horrendously is worrying within itself, as it suggests a lack of empathy.

Similarly, Trump also built his election campaign on the promise that he would build a wall across the Mexican border in order to keep illegal immigrants out of the country. Clearly, the nationalist rhetoric is a selfish and discriminatory one as anti-immigration policy suggests that the disadvantaged don't matter in American society and prospective immigrants are inferior to Americans.

Nationalists argue that banning immigration keeps America safe as it reduces the risk of terrorism. However, of 89 terrorist attacks between 2011 and 2015 only 11 were carried out by Muslims in the USA and 18 were actually targeted at Muslims. Evidently, Islamophobia causes more problems in America than the Muslim citizens who are just trying to build a life for themselves. The spread of false information about immigration promotes racism and hatred within America, making it a less safe place for everybody.

In conclusion, the rise of the nationalist ideology is clearly the most important and worrying political problem of the modern age as it pits those of different religions and ethnicities against each other, at a time when we should be coming together to fight racism and discrimination. The most worrying thing about this ideology, specifically in America, is how a liberal country, that 
once fought for its own freedom from the British, has adopted it and how the government spreads a message of hatred and limited freedoms for minorities. The USA once set the precedent for what a free world should look like, the rise of nationalism threatens to tear this vision apart.

\section{Annotated Bibliography}

My most important problem is the rise of nationalism in the USA, the role of Donald Trump and the appeal of nationalism to its supporters will be the basis for my research.

\section{Amaya, H., 2018. White Nationalism and Publicness in the United States. Javnost - The} Public, 25(4), pp.365-378.

Amaya writes in the form of a heuristic inquiry, alternating between historic and discursive narratives as he recalls the events of a white nationalist rally in Charlottesville and goes on to discuss his theory that these rallies will increasingly become part of political participation due to high profile nationalists such as Stephen Bannon. Amaya suggests that these rallies will promote fascism, racism and violence in America, which he considers to be dangerous ideologies. This article will be useful for my own research as Amaya gives an insight into what a nationalist rally is like, furthering my understanding of the way in which nationalists participate in politics. Furthermore, the rationale behind Amaya's view that nationalism facilitates racism and violence will help me to form my argument surrounding the reasons why the rise of nationalism in the USA is such a big political issue today.

\section{Bonikowski, B. \& Dimaggio, P., 2016. Varieties of American Popular}

\section{Nationalism. American Sociological Review, 81(5), pp.949-980.}

Bonikowski and Dimaggio examined quantitative data collected through survey research which produced a longitudinal survey by the International Social Survey Programme. Participants where asked whether they agreed or disagreed with statements such as 'America is a better country than most other countries' and 'it is important to have been born in America'. Bonikowski and Diamaggio used this research in order to theorise that there are many different varieties of American nationalism, ranging from 'national identification' to 'national hubris'. This article will be useful for my research as it provides data on what Americans actually think about nationalist ideas and Bonikowski and Diamaggio's identification of the different varieties on nationalism will help me narrow down what specifically troubles nationalists about events in America.

\section{Bonikowski, B., 2016. Nationalism in settled times. Annual Review of Sociology, 42, pp.427-449.}

Bonikowski's article is a heuristic inquiry in which he uses a discursive narrative in order to explore the link between individual nations and nationalist sentiments and how these vary across populations and time. Bonikowski uses his theory regarding the varieties of nationalism 
to define how ideas about the nation and how it infiltrates the everyday lives of its citizens impacts upon national identification, explaining how the nation becomes a symbolic of the struggles of everyday life. This will be useful for my research as Bonikowski discusses the role of the nation in creating nationalist sentiment throughout its population which will help me identify where the ideology spreads from and question if nations are promoting a dangerous ideology and therefore creating a global issue. I can also use Bonikowski's research to compare how he describes the relationship between nations and nationalism with what is currently taking place in the US government in order to determine if it promotes the ideology.

Brands, $H ., 2017$. US grand strategy in an age of nationalism: fortress America and its alternatives. The Washington Quarterly, 40(1), pp.73-94.

Brands uses a heuristic inquiry, using a historical narrative in order to discuss the history of nationalism in America and how policy making has impacted its growth. Brands discusses how the history of US policy has caused what Brands described as 'fortress America'. Brands theorises that Trump's policies are causing a new hard-line form of nationalism which is based on isolationism as many believe that America's global openness has actually weakened it meaning that America should close itself off and promote its own interests as a global superpower. Brands' theory will be useful within my own research as it gives a clear indication of what kind of ideology Trump's policies could lead to and perhaps what is an ideal policy to nationalists which will enable me to examine why Trump has so many supporters.

\section{Giroux, H.A., 2017. White nationalism, armed culture and state violence in the age of Donald Trump. Philosophy \& Social Criticism, 43(9), pp.887-910.}

Giroux uses grounded theory in order to explore how war culture and white nationalism link together in Donald Trump's America. He uses quantitative empirical data collected from various pieces of research to form his theory about the future of America. Giroux theorises that Trump's administration will be a step back for America, with politics centring around white Christians and the economy working in favour of the elite. Giroux's research will be useful to me as he provides a clear theory on where American history could be headed because of the rise of nationalist figures such as Donald Trump. This will enable me to develop my own argument on why nationalism is a dangerous ideology as clearly expert opinion shows that it will lead to more inequality within American society.

\section{Inglehart, R. and Norris, P., 2016. Trump, Brexit, and the rise of populism: Economic} have-nots and cultural backlash.

Inglehart and Norris have used grounded theory in order to discuss their theories on the global rise of populism. Quantitative empirical data from various other forms of research is used in order to back up the theories of the authors. Inglehart and Norris examine two theories in order to explain the rise of populism, economic insecurity and cultural backlash, which is described as 
a negative reaction to change in society. This study will be useful for my research as it focuses on how both economic and cultural issues impact upon electoral behaviour, with the victory of Donald Trump being one of the examples used. This will further my understanding of the reasons that may have been behind Trump's victory and why his policies are appealing to a large number of Americans. Inglehart and Norris particularly focus on the anti-elite aspect of these ideologies which will be a key theme throughout my own research. Furthermore, the study explores issues in Europe, such as Brexit which will give me a wider understanding of the populist and nationalist movements as a whole, which is important in order to understand the global appeal of the ideology.

Lieven, A., 2016. Clinton and Trump: Two Faces of American Nationalism. Survival, 58(5), pp.7-22.

Lieven uses a heuristic inquiry to create a discursive narrative that discusses two very different types of nationalism in America. Lieven theorises that two different forms of nationalism will come to the forefront of American politics and he aims to prove this through describing what is appealing about both of the forms that he identifies and how they are becoming increasingly relevant. Throughout the article, Lieven compares and contrasts the politics of Hilary Clinton and Donald Trump, explaining how they both appeal to different types of nationalists. This article will aid my research as Lieven discusses two prominent figures in US politics and popular culture and their link to the nationalist ideology. His work on Trump will be particularly useful as my research will be heavily based on Trump's role in promoting nationalism through the policies he has attempted to implement throughout his time in office.

\section{Macdonald, P.K., 2018. America First? Explaining Continuity and Change in Trump's} Foreign Policy. Political Science Quarterly, 133(3), pp.401-434.

Macdonald uses a heuristic inquiry to discuss a range of case studies related to how well Donald Trump has carried out American foreign policy throughout his time in office. Before his research, the author theorised that Trump would be unable to carry out his desired foreign policy. Macdonald finds that Trump's foreign policies weren't in line with his campaign policies as within nine case studies out of nineteen he simply followed what Obama, his predecessor, had done. These findings will be useful for my research as it will help me to analyse how viable nationalist policies are within a democratic government, enabling me to better assess if the ideology is built to last in the context of the US government.

\section{Mutz, D.C., 2018. Status threat, not economic hardship, explains the 2016 presidential vote. Proceedings of the National Academy of Sciences, p.201718155.}

Mutz used survey research in order to carry out a longitudinal panel survey in which he examined the correlation between the wealth of the participant and how they felt towards both republican and democrat policies towards issues such as immigration, trade and China. From 
his research, Mutz has theorised that fear for personal wealth didn't sway the 2016 election in favour of Donald Trump and the Republicans but rather a perceived status threat by the wealthy. Mutz describes the status threat as a feeling that America's global dominance is being threatened by issues such as the rise of China. This is useful for my research as the results of this study begin to provide a reason why nationalism is on the rise in America as the study showed that many America's feared for their place on the global stage which shows why Donald Trump's 'American first' narrative has become appealing.

\section{Swain, C.M. \& Nieli, R., 2003. Contemporary voices of white nationalism in America, Cambridge, UK ; New York: Cambridge University Press.}

The authors use ethnographical research, collecting qualitive data in the form of casual interviews with ten Americans who identify as white nationalists. The authors theorise that by making these views well known, people are more likely to challenge them. This will be important for my research as it gives an insight into the actual views of white nationalists in America which will enable me to further understand the ideology and its place in American society. By using Swain and Nieli's research I will be able to analyse why some Americans choose to identify as nationalists and gain an understanding of the development of nationalism. As the article was published in 2003, I will be able to compare the nationalist ideas of over a decade ago to current nationalist ideals.

\section{Most Important Problem - Nationalism in America}

The nationalist ideology has been on the rise in America since the 2016 presidential elections in which Donald Trump became president. There is a debate among scholars regarding the definition of nationalism. Definitions include staunch allegiance to the state leading to intolerance of criticism towards it (Schatz, Staub \& Lavine, 1999) and the white populations desire for dominance (Walzer, 1990). Some of these definitions suggest that nationalism is a dangerous ideology which has racist undertones and furthers the idea of white supremacy and dominance, evident through nationalist rallies and support for Confederate statues. The policies of the Trump administration such as immigration policy can be considered racist and harmful to diversity in America. Trump is also promoting militarisation and inequality within the economy by promoting policies that appeal to his 'make America great again' narrative which greatly appealed to nationalists in the election. In order to understand this ideology and why it is becoming one of the most important political problems of the modern day, it is important to understand how and why nationalism has become a popular way of thinking in America and how it can impact on not only the future of the USA but the future of the world.

The key to understanding why nationalism is a dangerous ideology and how it rose to prominence, is understanding popular ways of thinking about patriotism and nationalism within America. Bonikowski and Dimaggio (2016) carried out a study in which they surveyed a 
group of Americans on their own patriotic sentiments in order to define certain categories of nationalism and determine which best fit the USA. Bonikowski and Dimaggio found that $57 \%$ of people believed that it is very important to have lived in America for the majority their lives and that $40 \%$ of people strongly agreed that America is better than most other countries in the world. Bonikowski and Dimaggio defined this as 'national hubris', suggesting that most Americans have a preference for their own country and citizens above all others. This explains how a figure such as Donald Trump won the 2016 presidential election, as his 'America first' rhetoric appeals to this kind of nationalist thought. Mutz (2018) has attempted to explain why Trump won the election, concluding that it was to a perceived feeling of status threat by well off Americans. Mutz describes status threat as the fear that America's global dominance will end, and China will take centre stage as the new world superpower. He theorises that Trump's 'make America great again' narrative appealed to these insecurities as the Trump administration promises to restore America to its perceived former glory. The prosperity of a nation correlates heavily to the feeling of a citizen's pride in the nation and their own national identity, suggesting that Trump's victory was down to his ideas about improving America on the global stage and putting America first. (Bonikowski, 2016). Both of these studies suggest that nationalism is on the rise in America due to pride in the nation, or hubris, being threatened by the economic rise of China and a strong feeling that America should be restored to its perceived former political and economic greatness.

The way nationalism in the USA has materialised has made it a dangerous ideology that is often linked to white supremacy and dominance over African-Americans. Many white nationalist protests have taken place in America, some of which have turned violent. At a protest by 'Unite the Right' in Charlottesville in August 2017, one woman was murdered, and nineteen people were injured suggesting that those promoting nationalist ideals are threatening security in America (Amaya, 2018). The protest started after a statue of Robert E. Lee, who fought for the Confederacy in the Civil War, was taken down. The Confederacy supported dehumanising policies including slavery, promoting a very difficult time in history for African-Americans as they were denied basic human rights (Amaya, 2018). Some academics argue that confederate statues have an important place in public memory, teaching the public not only who they are now, but who they used to be (Sanchez \& Moore, 2015). However, others argue that confederate statues simply celebrate those who fought against human freedom and valid nationalistic views in the present day, meaning that they are inherently racist and offensive towards the AfricanAmerican population (Leib, 2002). Evidently, nationalist rallies and protests surrounding confederate statues promote the idea that white supremacy and slavery is a part of history that should be fondly remembered, arguably continuing to create racial divisions. A recent survey by the NPR (2017) found that 92\% of African-Americans believe that they are discriminated 
against in American society, suggesting that nationalist rallies and campaigns are making minorities feel unsafe. Part of this discrimination is the normalisation of Confederate history, with statues glorifying men who supported the practice of slavery and nationalists insisting that they should remain in city centres across America. Amaya theorises that rallies and protests will increasingly become part of political participation for nationalists, as high-profile nationalists such as Stephen Bannon, a former White House chief strategist, continue to promote and attend them. The findings of the NPR suggest that this would have a negative impact upon the AfricanAmerica community, who already fear for their safety which suggests that nationalism is becoming a dangerous force in America, damaging equality and the right of all citizens to feel safe.

Nationalism is an ideology which arguably has racist undertones, as many nationalists seek to cut America off from citizens of foreign countries. President Trump has been accused of promoting racist policies throughout his time in office, including his plan to build a wall on the Mexican border, banning citizens from seven Muslim majority countries from entering the USA and separating illegal immigrants from their families. Within executive order 13769, more commonly known as the travel ban, Trump (2017) describes the order as a way 'to protect the American people from terrorist attacks by foreign nationals.' Trump's separation of American people from foreign nationals in this statement suggests that citizens of other countries are different to Americans, and consequently they are a threat, a sentiment that is often peddled in American nationalism. This could be considered a racist view, as the countries chosen to be included in the travel ban are Iran, Libya, Somalia, Syria and Yemen which are Muslim majority countries. Trump's choice of countries suggests that foreign nationals are a threat simply due to their religion. This links to nationalist ideology as Trump suggests that America is closing itself off from other countries across the globe because the perceived protection of the American people is more important than appearing to be politically correct and treating people of all religions equally. Many nationalists believe that America's global openness has weakened the country. Trump's policies try to appeal to nationalists by the creation of 'fortress America' (Brands, 2017). This model appeals to nationalists as it promotes America's isolation from the rest of the world as a way of furthering its own interests and the superiority of the American people. Brands describes this form of hardline nationalism as being disastrous for America as a superpower, as by cutting itself off America will no longer wield the extensive power they currently do across the world. Furthermore, the Trump administration risks China taking over as the new world superpower as Trump seeks to operate outside of the World Trade Organisation, making way for China to change policies to suit their own self-interest (Brands, 2017). As identified by Mutz, Americans fear the rise of China, showing that the nationalist 
ideology contradicts itself by shutting itself off from the world for both racist and protectionist reasons, making Trump's use of the ideology inherently flawed.

The most important problem about nationalism in America, is what the ideology could lead to in the future and how this could impact upon the country and its citizens. The rise of nationalism could lead to the public sphere being dominated by white and Christian individuals, which could lead to a return to the economy only working for the elite rather than normal Americans along with increasing militarisation (Giroux, 2017). In early 2018, tensions between Trump and the North Korean leader, Kim Jong Un, greatly increased. Trump threatened to use armed force against the country, increasing militarisation in order to assert American's superiority and ultimate dominance over the rest of the world, a concept which greatly appeals to nationalists (White, 2017). American's nationalist and aggressive tendencies have impacted upon global relations, with countries such as South Korea perceiving Trump's policies on North Korea to be reckless which threatens American's position on the global stage (White, 2017). This could impact upon the future of the USA as it is beginning to be perceived as an unpredictable entity under the Trump administration, arguably making it untrustworthy rather than a reliable global superpower. In addition, nationalism could lead to a future of further class inequality in America. Trump has been known to employ neo-liberals, such as Rex Tillerson as Secretary of State, to manage the economy (Giroux, 2017). Neo-liberalism can be described as the desire for free markets without state intervention (Stokes, 2018). Tillerson has a tendency to peddle big bank and corporate interests, letting them have a say in how the economy is ran. This links to nationalism as the Trump administration is trying to improve the economy to fit into the 'make America great again' narrative whilst forgetting about the interests of minorities in favour of those of the elites (Giroux, 2017). The nationalist desire to improve all aspects of America and display a strong global image will create a future with an unequal society, allowing an economy in which elites are able to promote their own interests rather than the government working to promote the interests of the public as this isn't the quickest way to improve the economy. In conclusion, the rise of nationalism in America is one of the most important political problems of today due to its anti-freedom sentiments. Those who follow this ideology often seek to reduce the freedoms of minorities, make them feel unsafe and close America off from the rest of the world. The treatment of minorities under the Trump administration is clearly unacceptable in a liberal democracy, with minorities reporting that they feel unsafe due to the actions of nationalists, something which the government hasn't tried to curb. Furthermore, nationalistic policies will only weaken Americans global standing in the future, the exact opposite of what nationalists seek to do. Aggressive and isolationist policies do not promote Americans interests internationally, as they leave the government without a say on global issues which could promote the rise of China as a superpower, something which many Americans reported that 
they feared. Overall, nationalism is harmful to both America and its citizens, presenting a backwards approach to the both international and domestic issues in a country which prides itself on being a dominant political innovator.

Bibliography

Amaya, H., 2018. White Nationalism and Publicness in the United States. Javnost - The Public, 25(4), pp.365-378

Bonikowski, B. \& Dimaggio, P., 2016. Varieties of American Popular Nationalism. American Sociological Review, 81(5), pp.949-980.

Bonikowski, B., 2016. Nationalism in settled times. Annual Review of Sociology, 42, pp.427-449. Brands, H., 2017. U.S. Grand Strategy in an Age of Nationalism: Fortress America and its Alternatives. The Washington Quarterly, 40(1), pp.73-94.

Giroux, H.A., 2017. White nationalism, armed culture and state violence in the age of Donald Trump. Philosophy \& Social Criticism, 43(9), pp.887-910.

Leib, J.I., 2002. Separate times, shared spaces: Arthur Ashe, Monument Avenue and the politics of Richmond, Virginia's symbolic landscape. Cultural geographies, 9(3), pp.286-312. Npr.org. (2017). Discrimination In America: Experiences and Views of African Americans. [online] Available at: https://www.npr.org/assets/img/2017/10/23/discriminationpoll-africanamericans.pdf?t=1544534046276 [Accessed 12 Dec. 2018].

Schatz, R.T., Staub, E. and Lavine, H., 1999. On the varieties of national attachment: Blind versus constructive patriotism. Political Psychology, 20(1), pp.151-174.

Stokes, D., 2018. Trump, American hegemony and the future of the liberal international order. International Affairs, 94(1), pp.133-150.

Trump, D. (2017). Executive Order Protecting the Nation from Foreign Terrorist Entry into the United States / The White House. [online] The White House. Available at:

https://www.whitehouse.gov/presidential-actions/executive-order-protecting-nation-foreignterrorist-entry-united-states/ [Accessed 12 Dec. 2018].

Walzer, Michael. 1990. “What Does It Mean to Be an American?” Social Research 57(3):591-614. White, H., 2017. Trump's North Korea Bluster Has Shattered US Standing As Global Leader. New Perspectives Quarterly, 34(4), pp.24-26. 


\section{Tables and Figures}

Table 1: Programme Structure

\begin{tabular}{|c|c|c|}
\hline Lecture & Seminar & Assessment \\
\hline \multicolumn{3}{|l|}{ Introduction to the module } \\
\hline \multicolumn{3}{|l|}{$\begin{array}{l}\text { Professional conduct and learning } \\
\text { agreement }\end{array}$} \\
\hline \multicolumn{3}{|l|}{ What is politics? } \\
\hline $\begin{array}{l}\text { Fields of Political Study I: Political } \\
\text { Philosophy, Political Economy, } \\
\text { Comparative }\end{array}$ & $\begin{array}{l}\text { Introduction to seminar structure and } \\
\text { procedures }\end{array}$ & \\
\hline $\begin{array}{l}\text { Fields of Political Study II: Area } \\
\text { Studies, International } \\
\text { Relations/Systems }\end{array}$ & & \\
\hline Writing for University I & $\begin{array}{l}\text { How good are you at managing writing } \\
\text { tasks? Self-evaluation }\end{array}$ & \\
\hline \multicolumn{3}{|l|}{ Writing for University II } \\
\hline Library lecture & Developing an idea into writing & \\
\hline \multicolumn{3}{|l|}{ Finding and Evaluating Sources } \\
\hline $\begin{array}{l}\text { Recognising Statistics Facts and } \\
\text { Opinions }\end{array}$ & Evaluating sources & Most Important Problem \\
\hline \multicolumn{3}{|l|}{ Discerning Bias } \\
\hline Thinking Critically & Evaluating statistics, facts and opinions & \\
\hline \multicolumn{3}{|l|}{ Approaches to Knowledge } \\
\hline $\begin{array}{l}\text { Research Methodology : The Broader } \\
\text { Strategies for Research }\end{array}$ & $\begin{array}{l}\text { How do you learn? Attitudes and } \\
\text { approaches to learning (self reflection) }\end{array}$ & \\
\hline \multicolumn{3}{|l|}{$\begin{array}{l}\text { Research Methods: The Tools Used } \\
\text { for Research }\end{array}$} \\
\hline $\begin{array}{l}\text { What is Theory? Foundational } \\
\text { Theories }\end{array}$ & Identifying theory exercise & Annotated Bibliography \\
\hline \multicolumn{3}{|l|}{ Contemporary Theory } \\
\hline The ABCs of Referencing & Referencing exercise & \\
\hline \multicolumn{3}{|l|}{ Bibliographies } \\
\hline \multirow[t]{2}{*}{ Identifying Employability Skills } & Essay surgery & \\
\hline & & $\begin{array}{l}\text { Essay submission } \\
\text { Seminar portfolio submission }\end{array}$ \\
\hline
\end{tabular}


Table 2: Mark History

\begin{tabular}{|ll|llllll|}
\hline & Cohort & Mean & Std. Dev. & Median & High mark & Pass & Fail \\
\hline $\mathbf{2 0 1 8 - 1 9}$ & 155 & 62.1 & 10.8 & 65 & 75 & 148 & 7 \\
\hline $\mathbf{2 0 1 7 - 1 8}$ & 143 & 57.7 & 7.7 & 59 & 69 & 140 & 3 \\
\hline $\mathbf{2 0 1 6 - 1 7} *$ & 166 & 58.1 & 8.1 & 59 & 68 & 162 & 4 \\
\hline $\mathbf{2 0 1 5 - 1 6}$ & 127 & 55.7 & 8.3 & 57 & 67 & 123 & 4 \\
\hline $\mathbf{2 0 1 4 - 1 5}$ & 122 & 56.5 & 8.2 & 58 & 69 & 66 & 120 \\
\hline $\mathbf{2 0 1 3 - 1 4}$ & 120 & 54.4 & 12.7 & 57 & 66 & 95 & 2 \\
\hline $\mathbf{2 0 1 2 - 1 3}$ & 97 & 59.5 & 5.5 & 60 & 66 & 6 \\
\hline
\end{tabular}

*Increase in enrolment was due to a University wide admissions 'bulge' related to the introduction of tuition fees in the UK and a lifting of the cap on enrolment. 